\section{Desarrollo \\ Profesional en las Ciencias de la Salud}

La revista Internacional Educación Médica/ Medical Education ha tenido desde su fundación en el año 1997, en la medida que le corresponde y en su ámbito de influencia, la voluntad de contribuir a la trans formación y a la innovación de la educación médica.

Desde el presente año 2003, la revista ha empezado una nueva singladura al haber pasado a manos de un nuevo Editor, la Fundación Privada Educación Médica. Una vez más en esta nueva etapa se considera que favorecer la transformación y la innova ción seguirán siendo misiones de esta publicación. No hemos dudado nunca de que la ética de los profesionales de las Ciencias de la Salud les ha conducido a ser un paradigma de profesional en permanente formación a lo largo de su vida. Pero en un momento en que la sociedad está sacudiendo los valores de las profesiones, no está por demás explicitarlos cuando se cree firmemente ellos. Por ello, atentos a los procesos de modernización, nos ha parecido oportuno mostrar nuestra sensibilidad a los valores del profesionalismo en general y muy en especial a uno de ellos como es el del desarrollo y mantenimiento de la competencia profesional, por lo que a nosotros nos concierne el continuum del aprendizaje: Pregrado, Postgrado y Desarrollo Profesional Continuo (DPC/CPD). Por ello, desde el presente número, la cabecera de la revista incluirá el título de la presente Editorial: Desarrollo Profesional en las Ciencias de la Salud.

En la misma línea ideológica que acabamos de exponer, la Fundación Educación Médica acaba de incorporar como nuevo patrón Institucional al Colegio Oficial de Médicos de Barcelona (Col-legi Oficial de Metges de Barcelona, COMB). Desde estas líneas nos felicitamos de recibir tanto al nuevo patrón como a su representante, ya que la presencia en el board de la Fundación de una corporación profesional tan sólida y prestigiosa como es el COMB aportará, por encima de todo, la voz de los valores de la profesión médica.

\section{Professional Development in Health Sciences}

Since its foundation in 1997 and within its area of influence, the international journal Educación Médica/ Medical Education had the willingness to contribute to transformation and innovation in medical education.

In the current year, the journal started a new direction since the Medical Education Private Foundation become its new editor. In this new period, to favour transformation and innovation will still be the main objectives of this publication. We never doubted that the ethics of Health Science professionals led them to be a paradigm of the professional in constant training throughout their life. At this moment, in which our society debates the professional values, it is worthy to state explicitly that we firmly believe in them. Current modernization processes lead us to be sensitive to the values of professionalism in general, and particularly to the development and maintenance of professional competence, which in our area is the continuum of the learning process: Undergraduate, Postgraduate and Continuous Professional Development (CPD/DPC). Therefore from the current issue on, the journal's header will indude the title of this editorial: Professional Development in Health Sciences.

Following this line of thought, the Barcel ona Medical Society ( $\mathrm{Col} \cdot$ legi Oficial de Metges de Barcelona, COMB) recently joined the Medical Education Foundation as a new institutional partner. From this editorial, we are pleased to welcome both, the new patron and its representative. The presence in the Foundation board of a solid and prestigious professional corporation as the COMB will provide, above all, the voice of the values of medical profession.

Barcelona, May 2003 